2. P. Gruber, Biomimetics in Architecture. Architecture of Life and Buildings, (New York: Springer Wien 2011), 275.

3. CollectedPapers, URL: https://collectedpapers.com.ua/ru/ plants_engineers_of_the_nature/yak-buv-stvorenij-krishtalevij-palac (date retrieved 24.06.2021).

4. Victoria amazonica, Victoria Regia, URL: https://n-dank.livejournal. com/109641.html (date retrieved 24.06.2021).

5. Capital Gate Tower, Abu Dhabi, URL: https://web.archive.org/ web/20170616220958/http:/www.ctbuh.org/TallBuildings/FeaturedTallBui ldings/CapitalGateTowerAbuDhabi/tabid/3380/language/en-

GB/Default.aspx (date retrieved 24.06.2021).

DOI https://doi.org/10.30525/978-9934-26-109-1-25

\title{
ДІЛОВА КУЛЬТУРА І ГЕНОМ ДІЛОВОЇ ДОСКОНАЛОСТІ БУДІВЕЛЬНОГО ВИРОБНИЦТВА - ОСНОВА КУЛЬТУРИ ВИРОБНИЧИХ ВІДНОСИН СУСПІЛЬСТВА
}

\author{
Савенко B. I. \\ доктор технічних наук, професор, \\ доктор будівниитва АБУ \\ професор кафедри організаиії і управління будівництвом \\ Київький національний університет будівництва і архітектури
}

Полосенко О. В.

аспірант

Київський національний університет будівництва і архітектури член-корреспондент АБУ

TOB HBO «Iнтериептор»

\section{Победа С. С. \\ аспірант}

Київський національний університет будівництва і архітектури м. Київ, Україна

Питання досконалості і якості вічне питання, як і саме будівництво. Для успішної діяльності будівельної організації дуже важливо мати замовлення, а для цього треба забезпечити конкурентоспроможність 104 
продукції на ринку і знайти свого споживача. Це можна зробити, вдосконаливши менеджмент .організації і впровадивши на підприємстві сертифіковану у відповідності з ISO 9001-2000 систему управління якістю. Головним принципом такої системи є постійне вдосконалення, що стимулює пошук проблемних факторів і їх вирішення. А це тільки перший крок, далі - Модель досконалості і активна наукова та інноваційна діяльність, створення генома ділової досконалості за підтримки Держави і суспільства. В період переходу до ринкових відносин і відкриття власних ринків для іноземних виробникв без підтримки і розвитку вітчизняного виробника веде до руйнування власних підприємств і і падіння економіки. Вихід один - розвивати і зміцнювати вітчизняні підприємства на базі інноваційних технологій та передової освіти і науки, створюючи геном ділової досконалості і високої культури виробництва.

Головною метою цієї роботи $є$ популяризація наукових i практичних напрацювань, як нових, так і давно відомих, але з різних причин підзабутих, не вивчених, часто проігнорованих з політичних мотивів. Використання позитивного досвіду в управлінні менеджментом підприємств,якістю продукції та іiї інвестиційною привабливістю, конкурентоздатністю. Сприяння розвитку будівельних організацій, як основи розвитку економіки України.

Аналіз розроблених систем управління якістю в будівельних організаціях АТ ХК «Київміськбуд» показав, що в ряді випадків система документів підприємства у сфері якості i менеджменту в цілому не ефективна, не актуалізована, недостатньо пророблена, не відображає вимог споживачів продукції, містить загальні і неконкретні формулювання, непов'язана 3 іншими елементами управління підприємством. Ці й інші недоліки приводять до того, що система менеджменту підприємства не відповідає очікуванням споживачів, а це призводить до зниження конкурентоспроможності продукції і втрати підприємством своїх позицій на ринку. Негативні явища в будівельному виробництві накладають руйнівний відбиток на виробничі відносини в економіці в цілому, бо будівництво дає роботу порядка 70 галузей економіки. Тому культура виробництва i виробничих відносин в будівництві безпосередньо впливає і на них [1]. Позитивним є в цьому плані напрацьований досвід роботи АТ ХК «Київміськбуд» i ВАТ ДБК-3, який, на жаль, швидко втрачається. ПАТ «ДБК-4», тепер компанія «Житлобуд» зберігає i розвиває СУЯ i прогресивний менеджмент, створюється геном ділової культури і досконалості, бо на чолі стоїть справжній лідер Герой України, академік Української 
академії наук та Академії будівництва України, президент будівельної палати України Шилюк П.С. [2]. Сьогодні дуже важливо надати науковометодичну допомогу фахівцям у частині розробки і впровадження системи управління якістю згідно 3 міжнародними стандартами ISO 9000-2000 (2015) сертифікувати iї i, вдосконалюючи, довести до рівня Європейської моделі досконалості Навчання i підготовка персоналу проводилась в Українській асоціації якості (Президент Калита П.Я.). Розробка і впровадження перших систем велись на базі ВАТ «ДБК-3» АТ ХК «Київміськбуд» за Президенства Поляченка В.А. і куратора-керівника управління іспекційного контролю якості АТ ХК «Київміськбуд» Массалова А.Г. [1; 2]. Побудова сучасних систем управління виробничих організацій на базі економікоматематичних методів та інформаційних технологій передбачає вирішення ряду проблем, пов'язаних 3 формалізацією процесу функціонування виробничої системи і постійного ії поліпшення, як вимагають міжнародні стандарти. Проте стохастичний (вірогіднісний) характер як внутрішніх, так i зовнішніх чинників вносять певну невизначеність (хаос) в дії виробничої організації i формують певний рівень ентропії, яка стає причиною втрати синергічності функціонування системи, нераціональних витрат ресурсів. Робляться спроби кількісного вимірювання цих властивостей систем, але точних надійних, однозначних методів поки що не існує, тому автоматизована чи роботизовано система не має підстав для прийняття однозначного рішення [3; 4]. Навіть у найдосконаліших машин інтуїція, як підказка з неба, відсутня. Людина ж як найдосконаліше творіння Природи на базі свого досвіду, над зусиль свого розуму і інтуїції, навіть в умовах невизначеності повинна приймати $\mathrm{i}$ приймає відповідальні рішення [5; 6].

Цей пошук продовжується. Здавалося 6 з появою Міжнародних стандартів типу ISO, моделей досконалості типу TQM з використанням логіки RADAR та інноваційних наукових підходів дали підприємствам і людям різних країн і економічних формацій ключі до успішного розвитку [7]. Але на заваді стала глобальна не доброчесна і жорстока конкуренція. Не усім вдалося опанувати, впровадити i розвинути ці передові ідеї 3 різних причин, об'єктивних i суб'єктивних. Постійні кризи різного масштабу та зміни керівництва держави в поєднанні 3 негативним зовнішнім впливом явно не сприяли впровадженню і розвитку прогресивних ідей. А можливості і люди, віддані цій справі були і поки що залишаються на Батьківщині. 3 практики розробки і сертифікації системи управління якістю 
(СУЯ), а фактично формування більш високого рівня менеджменту будівельної організації комбінатного типу (ВАТ ДБК-3 м. Київ) для створення системи обов'язкових документів СУЯ згідно міжнародних стандартів ISO 9001-2000, зокрема головної настанови НЯ-01, а також Політики (місіі) і цілей підприємства в сфері якості необхідною i головною процедурою було проведення анкетування усього персоналу за визначеною формою. I тільки на основі результатів такого широкого анкетування стало можливим формування Політики і цілей підприємства та затвердження головних настанов (методик) функціонування підрозділів і управління комбінату. Кропітка робота, підготовка робочої групи, формування і функціонування робочої групи та 3 якості, уповноваженого керівництва приведення у відповідність зі стандартом ISO 90012000 документації і усіх прцесів консолідувало і покращило функціонування управлінських і виконавчих елементів комбінату.[1,8] Унікальна ситуація виникла в перші роки незалежності України. Паралельно з адміністрацією, ще державною, а згодом комунальною і акціонерною,діяли колективні органи - ради трудових колективів підрозділів. Представницькі виборні органи, перед якими щомісячно на усіх рівнях звітували i ставили завдання на наступний місяць (квартал, рік) керівники підрозділів і всієї компанії ( до 2013 р. це ще було ВАТ ДБК-3 АТ ХК Київміськбуду). Це було незвично, недовго, але ефективно.

\section{Основні висновки:}

1. Впровадження ефективного менеджменту підприємства і системи управління якістю спонукає організацію до визначення основних процесів виробництва та їхніх параметрів, розробки схеми процесів, політики, місії, цілей, постійний моніторинг і аналіз виконання 3 подальшим коригуванням і визначенням домінантних факторів, що впливають на якість продукції і їі конкурентні можливості.

2. Вирішальне значення має формування високої культури виробництва, генома дідової досконалості організацій, що за підтримки держави і суспільства позитивно впливає на виробничі сили та виробничі відносини в цілому в державі.

\section{Література:}

1. Менеджмент якості в будівництві і геном ділової досконалості організації : монографія / Савенко В.I., Доценко C.I., Пальчик C.I., Калита П.Я. та ін. Київ. УАН : Центр учбової літератури, 2018. 230 с.

2. Савенко В.І. Оптимальні методи управління будівельною організацією комбінатного типу. Текст / Савенко B.I., Доценко C.I., 
Клюєва В.В., Терещук М.О. Управління розвитком складних систем (УРСС) : наукове видання КНУБА. № 35. К. 2018. С. 147-154. URL: http://urss.knuba.edu. Ua Copernicus Google.

3. Савенко В.І. Генетичний підхід до ділової досконалості та ізоморфізм структури будівельної організації : тексти тез доповідей Савенко В.І., Доценко С.І., Клюєва В.В., Пальчик С.П. 8-а Міжнародна конференція. КЗЯТПС ЧНТУ. Чернігів. 2018. С. 101-102.

4. Савенко B.I. Ентропія як прояв системної та діалектичної сутності будівельної організації комбінатного типу : тексти тез доповідей Савенко В.І., Пальчик С.П., Клюєва В.В. Победа С.С. УРСС КНУБА. Вип. № 36 КНУБА.К. 2018. С. 142-147 URL: http://urss.knuba.edu.UaCopernicusGoogle.

5. Савенко В.I. Інтелектуальні інформаційні інструменти розвитку виробничої системи енергетичного менеджменту та підприємства в цілому : тексти тез доповідей Савенко B.I., Доценко С.І., Пальчик С.П, Клюєва В.В., Терещук М.О. УРСС КНУБА. Вип. № 37. КНУБА. К. 2019. С. 195-204. URL: http://urss.knuba.edu.UaCopernicus Google.

6. Савенко В.І. Розвиток виробничої організації на основі впровадження системи управління якістю та енергоефективних науковомістких технологій : тексти тез доповідей Савенко B.I., Клюєва В.В., Пальчик С.П. 7-а Міжнародна конференція. КЗЯТПС ЧНТУ. Чернігів. 2017. С. 102-104.

7. Модель досконалості EFQM. Брюссель. 2011. EFQM : офіційний сайт. URL: http://www.efqm.org/the-efqm-excellence-model95. Калита П.Я. Головне ланка, або як витягнути ланцюг соціально-економічних проблем (на прикладі України). Стандарти і якість. 2010. № 1. С. 8-13.

8. Савенко В.І. Організаційні виробничі системи в світлі загальної організаційної науки та сучасного кадрового менеджменту : текст Савенко В.I., Пальчик С.П., Нестеренко I.С., Терещук М.O. Клюєва В.В. УРСС КНУБА. 2018. № 34.

9. В.І. Савенко. Генетичний підхід до ділової досконалості та ізоморфізм структури будівельної організації : тексти тез доповідей Савенко В.І., Доценко С.І., Клюєва В.В., Пальчик С.П. 8-а Міжнародна конф. КЗЯТПС ЧНТУ Чернігів. 2018.

10. Шаповалова I.C. Соціогенетичний підхід у вивченні організаційної культури. Наукові відомості БелГУ. Білгород: Вид-во БелГУ. 2009. № 5. С. 159-167.

11. Дослідження i математичне моделювання організаційних структур та виробничих процесів будівельних організацій комбінатного 
типу : монографія / Савенко B.I., Доценко C.I., Нестеренко I.C., Куліков П.М. та ін. УАН : Центр учб. літ. К. 2018. 124 с.

12. Савенко В.І. Інтелектуальні інформаційні інструменти розвитку виробничої системи енергетичного менеджменту та підприємства в цілому : тексти тез доповідей Савенко В.І. Доценко С.І. Пальчик С.П, Клюєва В.В. Терещук М.О. УРСС. Вип. № 37. КНУБА. К. 2019. С. 195-204. URL: http://urss.knuba.edu. Ua Copernicus Google.

DOI https://doi.org/10.30525/978-9934-26-109-1-26

\section{АНАЛІЗ СВІТОВОГО ДОСВІДУ УТРИМАННЯ АВТОМОБІЛЬНИХ ДОРІГ У ЗИМОВИЙ ПЕРІОД}

Смірнов А. М. аспірант кафедри транспортного будівниџтва та управління майном Національний транспортний університет м. Київ, Украӥна

Зимове утримання доріг - це завжди дорогий і складний процес. На жаль, у більшості випадків погода залишається складно передбачуваним явищем незалежно від країн світу. Ефективний контроль снігу та льоду на автомобільній дорозі $\epsilon$ важливою функцією для уряду держав, щоб забезпечити, наскільки це можливо, безперешкодний дорожній рух, для комфортного пересування в зимовий період між країнами світу. Практика, стандарти та рівень обладнання відрізняються між собою в країнах Європа та світу $[1 ; 2]$. Вартість аварій та травми внаслідок дорожньо-транспортних пригод $\epsilon$ істотними, так що заходи, спрямовані на подальші дії поліпшення зимового режиму обслуговування, ймовірно, принесе істотну користь для учасників дорожнього руху.

Сьогодні у світі існують різноманітні підходи до утримання автомобільних шляхів у зимовий період. Наприклад, Фінляндія має украй децентралізовану структуру обслуговування доріг. Там регіональні центри укладають договори із підрядниками, чітко включаючи в них цільові показники якості. Загалом підрядник має забезпечити цілодобовий безпечний проїзд дорогами. Натомість конкретний вибір 